\title{
STRATEGI MENINGKATKAN KETERAMPILAN BERBICARA PESERTA DIDIK KELAS V SEKOLAH DASAR MELALUI PENINGKATAN KECERDASAN INTERPERSONAL DAN KEPERCAYAAN DIRI
}

\author{
Rima Rahmawati ${ }^{1}$, Gusti Yarmi ${ }^{2}$, Lidwina Sri Ardiasih ${ }^{3}$ \\ Pendidikan Dasar, Universitas Terbuka ${ }^{1,3}$ \\ Pendidikan Dasar, Universitas Negeri Jakarta ${ }^{2}$ \\ Email: gustiyarmi67@gmail.com²
}

\begin{abstract}
Abstrak
Sebagai bentuk upaya peningkatan kualitas pendidikan Indonesia, penelitian ini bertujuan untuk menganalisis korelasi antara kecerdasan interpersonal $\left(\mathrm{X}_{1}\right)$ dan kepercayaan diri $\left(\mathrm{X}_{2}\right)$ terhadap keterampilan berbicara peserta didik (Y) kelas V sekolah dasar. Penelitian ini menggunakan pendekatan kuantitatif dengan teknik korelasional. Sampel dalam penelitian berjumlah 105 orang. Penentuan sampel menggunakan teknik cluster random sampling. Seluruh proses pengambilan data dilakukan sebelum pandemi COVID-19 yaitu pada bulan Oktober hingga Desember 2019. Dari hasil analisis, didapatkan bahwa terdapat korelasi signifikan ke arah positif antara kecerdasan interpersonal dan keterampilan berbicara dengan sumbangan efektif sebesar $44 \%$, serta terdapat korelasi signifikan ke arah positif antara kepercayaan diri terhadap keterampilan berbicara dengan sumbangan efektif sebesar $55,4 \%$. Secara simultan, keduanya memiliki korelasi signifikan ke arah positif terhadap keterampilan berbicara peserta didik kelas V. Secara praktikal, dari hasil dari penelitian ini, pengajar diharapkan dapat melakukan observasi serta meningkatkan kecerdasan interpersonal dan kepercayaan diri peserta didik sebagai upaya meningkatkan keterampilan berbicara peserta didik.

Kata Kunci : Kecerdasan Interpersonal, Kepercayaan Diri, Keterampilan Berbicara, Kuantitatif, Korelasional
\end{abstract}

\begin{abstract}
As an attempt to improve the quality of education in Indonesia, this study aims to analyze the correlation between interpersonal intelligence $\left(X_{1}\right)$ and self-confidence $\left(X_{2}\right)$ on the students speaking skills $(Y)$ in grade $V$ elementary school. This study occupied a quantitative approach with correlational techniques. The sample in this study amounted to 105 people. The sample was determined using the random cluster technique. The entire data collection process was carried out before the COVID-19 pandemic, from October to December 2019. From the analysis, it was found that there was a significant positive correlation between interpersonal intelligence and speaking skills with an effective contribution of $44 \%$, and there was a significant positive correlation between selfconfidence in speaking skills and an effective contribution of 55.4\%. Simultaneously, both of them have a significant positive correlation towards the speaking skills of grade V students. Practically, from this research, teachers are expected to be able to make observations and to improve interpersonal intelligence and self-confidence of students as an effort to improve students' speaking skills.
\end{abstract}

Key Words : Interpersonal Intelligence, Self-Confidence, Speaking Skills, Quantitative Approach, Correlational

\section{PENDAHULUAN}

Melalui Kurikulum 2013 (K13), keterampilan berbicara merupakan salah satu keterampilan yang ingin dikembangkan dari peserta didik. Secara harfiah, berbicara merupakan proses komunikasi lisan untuk mengungkapkan gagasan serta pemikiran kepada khalayak
[1]. Pada hakikatnya, keterampilan berbicara merupakan salah satu aspek yang sangat penting untuk dimiliki oleh peserta didik karena akan berimpak langsung pada proses belajar mengajar peserta didik di sekolah. Dengan keterampilan berbicara yang baik, secara otomatis peserta didik akan dengan mudah mengembangkan 
kemampuan dalam berpikir, membaca, menulis dan menyimak karena mereka akan terlatih dalam mengungkapkan gagasan, mengorganisir, klarifikasi, berdiskusi dengan orang di sekitarnya secara lisan.

Jika seseorang memiliki keterampilan berbicara yang baik, setidak-tidaknya ada dua keuntungan yang akan didapatkan yaitu keuntungan sosial dan professional [2]. Secara aspek sosial, keterampilan berbicara akan sangat mempengaruhi kemudahan dalam menjalin interaksi sosial. Sedangkan secara aspek profesional, keterampilan berbicara akan berpengaruh untuk kegiatan-kegiatan seperti membuat pertanyaan, berdiskusi dengan berbagai lawan bicara, bahkan menyampaikan aspirasi secara formal maupun non-formal di depan umum.

Pentingnya keterampilan berbicara juga diungkapkan oleh Peter Hyman, pendiri School 21. Sekolah tersebut terletak di London (Inggris) serta berfokus pada meningkatkan keterampilan berbicara (oracy) peserta didik. Faktanya, perkembangan kemampuan numerik dan literasi tidak seimbang dengan kemampuan berbicara peserta didik. Akibatnya, banyak sekali peserta didik yang malu serta takut dalam berbicara di depan kelas karena selama ini hanya berfokus pada kemampuan kognitif saja. Menurutnya, keterampilan berbicara merupakan sebuah hal yang sangat besar. Efek dari terjalinnya komunikasi yang efektif, peserta didik akan mendapatkan kesuksesan dari segi moral dan profesional kelak di kemudian hari [3].

Pernyataan Peter Hyman tersebut diperkuat dengan fakta di lapangan yang menunjukkan bahwa masih banyak ditemukan peserta didik sekolah dasar yang memiliki keterampilan berbicara yang masih rendah. Hal ini diperkuat oleh penelitian tentang kemampuan berbicara peserta didik sekolah dasar kelas tinggi di salah satu sekolah dasar di Purbalingga [4]. Didapatkan hasil bahwa kemampuan berbicara peserta didik yang masuk dalam kategori kurang baik adalah 32,25\%, kategori cukup baik 41,93\%, kategori baik $25,80 \%$ dan kategori sangat baik $0 \%$. Selain itu, penelitian menyatakan hal serupa yaitu sebanyak $66,67 \%$ peserta didik kelas tinggi di salah satu sekolah dasar di Bekasi memiliki kemampuan berbicara yang rendah [5]. Atas dasar tersebut, guru sebagai fasilitator memiliki peran dalam meningkatkan keterampilan berbicara peserta didiknya. Ada banyak metode dalam meningkatkan keterampilan berbicara peserta didik antara lain dengan meningkatkan kecerdasan interpersonal serta kepercayaan diri dari peserta didik tersebut.

Pengaruh kecerdasan interpersonal terhadap keterampilan berbicara peserta didik pernah diteliti secara eksperimental dengan analisis kuantitatif oleh peneliti lain. Studi yang dilakukan oleh Pishgadam memperlihatkan adanya hubungan antara kecerdasan emosional terhadap empat jenis kemampuan berbahasa yaitu berbicara, menulis, membaca dan mendengarkan [6]. Kecerdasan emosional yang diteliti melingkupi kecerdasan interpersonal, kecerdasan intrapersonal, manajemen stress, sikap adaptif, dan suasana hati (general mood). Metode yang digunakan oleh Pishgadam adalah analisis korelasional kuantitatif dengan responden sebanyak 508 mahasiswa tahun kedua. Dari studi korelasional, faktor utama dari kecerdasan emosional yang sangat mempengaruhi kemampuan berbicara adalah kecerdasan interpersonal, intrapersonal dan suasana hati.

Sejalan dengan hal tersebut, terdapat penelitian tentang korelasi secara kuantitatif antara kecerdasan interpersonal 
dan kecerdasan verbal terhadap kemampuan berbicara pada peserta didik kelas X [7]. Dari studi eksperimental didapatkan kecerdasan interpersonal dan kecerdasan verbal berkontribusi secara berurutan sebesar $40 \%$ dan $20 \%$ terhadap kemampuan berbicara. Dalam penelitian tersebut juga dijelaskan bahwa beberapa peserta didik diindikasi memiliki kepribadian introvert yang secara langsung berdampak pada kemampuan berbicara peserta didik.

Penelitian selanjutnya juga mendapatkan hasil yang serupa. Mata pelajaran Bahasa Inggris dipilih sebagai wadah penilaian keterampilan berbicara peserta didik [8]. Responden yang dipilih adalah peserta didik kelas VII sebanyak 32 orang. Hasilnya didapatkan bahwa kecerdasan interpersonal mempengaruhi keterampilan berbicara peserta didik secara signifikan. Dari ketiga studi eksperimental tersebut, dapat diindikasikan bahwa terdapat korelasi positif dari kecerdasan interpersonal dengan keterampilan berbicara peserta didik.

Sementara itu, korelasi antara kepercayaan diri terhadap kemampuan berbicara di depan umum pernah diteliti oleh beberapa orang. Dari penelitian yang dilakukan dengan pendekatan studi literatur yang pernah dilakukan didapatkan bahwa terdapat korelasi yang sangat signifikan antara kepercayaan diri seseorang dengan kemampuan berbicara, terutama di depan umum [9]. Penelitian yang dilakukan tersebut secara langsung mendukung pernyataan Arsjad [1] bahwa salah satu aspek di luar kebahasaan yang dapat mempengaruhi keterampilan berbicara adalah keberanian yang juga berasal dari kepercayaan diri.

Sementara itu, dari pendekatan eksperimental menganalisis secara kuantitatif korelasi antara kepercayaan diri dengan keterampilan berbicara peserta didik dalam mata pelajaran Bahasa Inggris [10]. Responden yang dipilih adalah peserta didik kelas VIII dari MTs Amaliyah Cibinong. Hasilnya didapatkan bahwa terdapat korelasi yang sangat kuat antara kepercayaan diri terhadap keterampilan berbicara peserta didik. Selain itu, dengan nilai determinasi koefisien sebesar 96,41\% mengindikasikan bahwa keterampilan berbicara peserta didik sangat dipengaruhi oleh faktor kepercayaan diri. Sejalan dengan penelitian tersebut, secara kuantitatif korelasi kepercayaan diri kaitannya dengan kecemasan dalam berbicara di depan umum [11]. Responden yang dipilih adalah mahasiswa sebanyak 261 orang dari fakultas dakwah. Hasilnya didapatkan bahwa terdapat korelasi terbalik antara kepercayaan diri dengan kecemasan berbicara dimana semakin tinggi kepercayaan diri maka semakin rendah kecemasan berbicara di depan umum. Dari hasil uji determinasi koefisien didapatkan bahwa terdapat kontribusi variabel kepercayaan diri sebesar $24,9 \%$ terhadap kecemasan berbicara di depan umum.

Sepaham dengan [11], juga terdapat penelitian secara kuantitatif tentang kepercayaan diri terhadap kecemasan berbicara pada mahasiswa. Dipilih responden yaitu mahasiswa yang berasal dari fakultas psikologi sejumlah 79 orang [12]. Hasil yang didapatkan sesuai dengan hasil penelitian [11] bahwa kepercayaan diri berkorelasi terbalik terhadap kecemasan berbicara di depan umum dengan nilai kontribusi sebesar 32,65\%.

Dengan penelitian-penelitian tersebut, secara eksperimental diindikasikan terdapat korelasi antara kecerdasan interpersonal dengan keterampilan berbicara. Selain itu, secara eksperimental dan studi literatur diindikasikan terdapat korelasi antara kepercayaan diri dengan 
keterampilan berbicara. Maka dari itu, diperlukan studi untuk menganalisis korelasi antara kecerdasan interpersonal dan kepercayaan diri dengan keterampilan berbicara peserta didik kelas $\mathrm{V}$ sekolah dasar.

Secara praktikal, dari hasil dari penelitian ini pengajar kelas V SD diharapkan dapat menyesuaikan desain metode pembelajaran Bahasa Indonesia yang berkaitan dengan keterampilan berbicara dan mengimplementasikannya. Melalui penelitian ini pengajar juga diharapkan dapat melakukan observasi serta meningkatkan kecerdasan interpersonal dan kepercayaan diri peserta didik sebagai upaya meningkatkan keterampilan berbicara peserta didik

\section{METODE}

Pendekatan yang digunakan pada penelitian ini adalah pendekatan kuantitatif dengan metode analisis korelasi variabel. Adapun variabel-variabel yang digunakan pada penelitian ini adalah variabel kecerdasan interpersonal $\left(\mathrm{X}_{1}\right)$, variabel kepercayaan diri $\left(\mathrm{X}_{2}\right)$ dan variabel keterampilan berbicara (Y). Penelitian ini membahas tentang korelasi antara variabel $\mathrm{X}_{1}$ terhadap variabel $\mathrm{Y}$, korelasi antara variabel $\mathrm{X}_{2}$ terhadap variabel $\mathrm{Y}$, serta korelasi antara $\mathrm{X}_{1}$ dan $\mathrm{X}_{2}$ terhadap $\mathrm{Y}$.

Responden yang dipilih adalah peserta didik kelas $\mathrm{V}$ sekolah dasar yang diambil dari SDN di Wilayah Binaan I Kecamatan Jatinegara, Jakarta Timur. Terdapat lima Sekolah Dasar di wilayah binaan V yaitu, SDN Rawa Bunga 01 Pagi, SDN Rawa Bunga 12 Pagi, SDN Rawa Bunga 11 Pagi, SDN Cipinang Besar Utara 08 Pagi, SDN Cipinang Besar Utara 05 Pagi, SDN Cipinang Muara 19 Pagi. Dari populasi tersebut, diambil sampel menggunakan teknik cluster random sampling. Dengan teknik tersebut, dipilih peserta didik kelas V dari SDN Rawa Bunga 01 Pagi dan SDN
Rawa Bunga 12 Pagi untuk dijadikan sampel penelitian. Total peserta didik yang dijadikan objek penelitian adalah 105 orang dengan rentang usia berada di antara 12 hingga 13 tahun. Seluruh proses pengambilan data dilakukan sebelum pandemi COVID-19 yaitu pada bulan Oktober hingga Desember 2019.

Pengumpulan data dilakukan dengan menggunakan instrumen berupa kuesioner untuk variabel $X_{1}$ dan $X_{2}$ serta tes praktik untuk variabel $Y$. Instrumen-instrumen tersebut disusun dari penurunan definisi konseptual dan operasional, sehingga masing-masing variabel dapat terukur. Sebelum dilakukan pengambilan data, kuesioner tersebut dilakukan pengujian validitas oleh ahli. Butir kuesioner variabel $\mathrm{X}_{1}$ dan $\mathrm{X}_{2}$ yang telah lolos uji validitas insrumen oleh ahli diujicobakan kepada 25 responden. Hasil uji coba tersebut lalu dilakukan analisis validitas menggunakan software SPSS versi 21 serta dilakukan eliminasi butir-butir pada kuesioner yang memiliki nilai tidak valid. Hal ini dilakukan agar kuesioner dapat merepresentasikan hasil yang tepat dan berkualitas. Setelah itu, dilakukan uji reliabilitas pada kuesioner dengan menggunakan teknik Cronbach's Alpha dengan asumsi galat (error) adalah 5\% $(0,05)$. Kuesioner dapat dikatakan reliabel jika nilai $r_{x y}$ lebih besar dari 0,6 [13].

Pengumpulan data diawali dengan menyebar kuesioner kecerdasan interpersonal. Setelah selesai, dilanjutkan dengan menyebar kuesioner kepercayaan diri. Kedua kuesioner tersebut disebar tanpa memberikan perlakuan apapun pada responden. Setelah itu, dilanjutkan dengan penilaian keterampilan berbicara. Adapun prosedur tes praktik keterampilan berbicara yaitu peneliti meminta peserta didik untuk bercerita di depan kelas dengan tema cerita rakyat yang dipilih sendiri oleh responden. 
Urutan pemanggilan responden dilakukan sesuai dengan absensi kelas.

Analisis data diawali dengan melakukan analisis statistika dasar yang meliputi analisis nilai modus $(M o)$, median $(M d)$, mean $(M)$, minimum (Min) dan maksimum Max). Setelah itu, hubungan data statistik tersebut ditentukan dengan ketentuan distribusi frekuensi [14] dimana:

1) Sebagian besar skor dikatakan memiliki kecenderungan rendah jika $M o<M d<M$.

2) Sebagian besar skor dikatakan memiliki kecenderungan tinggi jika $M o>M d>M$.

3) Skor dikatakan memiliki kecenderungan normal jika $M o=M d=M$.

Setelah analisis statistika dasar, analisis dilanjutkan dengan uji hipotesis. Agar hasil uji hipotesis tidak bias, maka perlu dilakukan uji asumsi klasik. Uji asumsi klasik yang digunakan di dalam penelitian ini adalah uji normalitas, uji linearitas dan uji korelasi. Uji normalitas digunakan untuk menentukan bagaimana distribusi galat (error) dari data yang didapatkan. Terdapat dua kategori distribusi galat yaitu galat terdistribusi normal dimana jika nilai signifikansi (sig) lebih besar dari asumsi taraf kesalahan dan galat terdistribusi tidak normal dimana jika nilai signifikansi (sig) lebih kecil dari asumsi taraf kesalahan. Galat terdistribusi normal berarti data yang didapatkan memiliki persebaran galat yang merata pada semua responden. Sementara itu, uji linearitas digunakan untuk mengetahui kelinieritasan antara variabel, dalam hal ini $X_{1}$ terhadap $Y$ dan $X_{2}$ terhadap Y. Jika keduanya bernilai linier, maka dapat dilanjutkan untuk melakukan uji hipotesis. Lalu uji korelasi digunakan untuk menganalisis keterkaitan serta keeratan antar variabel. Tingkat keeratan ( $r$ ) tersebut akan berkisar antara $-1 \leq \mathrm{x} \leq 1$ dengan kriteria sebagai berikut:
1) Jika $r$ bernilai negatif $(r=-)$ memiliki arti bahwa korelasi antar kedua variabel adalah negatif. Maksudnya fluktuasi nilai salah satu variabel tidak akan mempengaruhi nilai variabel yang lain.

2) Jika $r$ bernilai $0(r=0)$ memiliki arti bahwa korelasi kedua variabel tersebut sangat lemah.

3) Jika $r$ benilai positif $(r=+)$ memiliki arti bahwa korelasi antar kedua variabel adalah positif. Maksudnya fluktuasi nilai salah satu variabel akan mempengaruhi nilai variabel yang lain.

Interpretasi tingkat korelasi dari hasil uji korelasi dapat dilihat pada Tabel 1.

\section{Tabel 1. Interpretasi Tingkat Korelasi}

\begin{tabular}{cc}
\hline Interval Koefisien & Tingkat Hubungan \\
\hline $0,00-0,19$ & Sangat Lemah \\
$0,20-0,39$ & Lemah \\
$0,40-0,59$ & Sedang \\
$0,60-0,79$ & Kuat \\
$0,80-1,00$ & Sangat Kuat \\
\hline
\end{tabular}

Setelah dilakukan uji asumsi klasik, dilakukan uji hipotesis dengan menggunakan teknik analisis regresi linear berganda yang meliputi uji hipotesis parsial (uji $t$ ) dan uji hipotesis simultan (uji $F)$ untuk mengetahui ada tidaknya pengaruh antar variabel penelitian. Uji $t$ diperlukan untuk menguji hipotesis pada satu variabel bebas terhadap satu variabel terikat. Jika nilai $t_{\text {hitung }}>t_{\text {tabel }}$ atau nilai signifikansi $($ sig) < galat maka hipotesis dapat diterima, namun jika $t_{\text {hitung }}<t_{\text {tabel }}$ atau nilai signifikansi ( $\mathrm{sig})>$ galat maka hipotesis ditolak.

\section{HASIL DAN PEMBAHASAN}

Dari hasil uji validitas kuesioner, serta eliminasi butir kuesioner yang tidak valid, didapatkan hasil seperti pada Tabel 2. 
Tabel 2. Hasil Uji Reliabilitas Variabel

\begin{tabular}{cccc}
\hline Kuesioner & Jumlah butil & $\boldsymbol{r}_{\boldsymbol{x} y}$ & Keterangan \\
\hline $\mathrm{X}_{1}$ & 30 & 0,940 & Reliabel \\
$\mathrm{X}_{2}$ & 25 & 0,923 & Reliabel \\
\hline
\end{tabular}

Setelah kuesioner dinyatakan reliabel, pengambilan data dilakukan dengan menyebar kuesioner variabel $\mathrm{X}_{1}$ dan kuesioner variabel $\mathrm{X}_{2}$ serta tes keterampilan berbicara (Y) pada responden. Hasil statistik dari ketiga variabel tersebut disajikan pada Tabel 3 .

\begin{tabular}{lccc}
\multicolumn{4}{c}{ Tabel 3. Statistik Deskriptif } \\
Penelitian & \\
\hline Parameter & $\mathbf{X}_{\mathbf{1}}$ & $\mathbf{X}_{\mathbf{2}}$ & $\mathbf{Y}$ \\
\hline Modus & 67,7 & 82,3 & 84,4 \\
Median & 74 & 76 & 84,4 \\
Mean & 75 & 76,1 & 82,2 \\
Minimum & 66,7 & 64,8 & 62,5 \\
Maksimum & 88,7 & 95,2 & 96,8 \\
\hline
\end{tabular}

Berdasarkan Tabel 3, diketahui bahwa parameter $\mathrm{X}_{1}$ (kecerdasan interpersonal) memiliki $M o<M d<M$, maka dapat dikatakan sebagian besar responden memiliki kecerdasan interpersonal yang rendah.

Selain itu, diketahui bahwa parameter $\mathrm{X}_{2}$ (kepercayaan diri) memiliki $M o>M d>M$, maka dapat dikatakan sebagian besar responden memiliki kepercayaan diri yang tinggi. Lalu, pada parameter $\mathrm{Y}$ (keterampilan berbicara) memiliki nilai $M o$, $M d$, dan $M$ yang cenderung mirip, maka dapat dikatakan responden memiliki keterampilan berbicara yang normal/ratarata.

Setelah analisis statistika dasar, selanjutnya dilakukan uji asumsi klasik. Hasil dari uji normalitas, uji linearitas, dan uji korelasi secara berurutan dapat dilihat pada Tabel 4, Tabel 5 dan Tabel 6.

Tabel 4. Uji Normalitas Data

\begin{tabular}{ccc}
\hline Sig & Kriteria & Keterangan \\
\hline 0,145 & $>0,05$ & Galat berdistribusi normal \\
\hline
\end{tabular}

Tabel 5. Uji Linearitas Antar Variabel Penelitian

\begin{tabular}{lccc}
\hline Variabel & $\begin{array}{c}\text { Sig. } \\
\text { Linearity }\end{array}$ & $\begin{array}{c}\text { Sig. Deviation } \\
\text { from linearity }\end{array}$ & Keterangan \\
\hline $\mathrm{X}_{1} \rightarrow \mathrm{Y}$ & 0,000 & 0,268 & Linear \\
$\mathrm{X}_{2} \rightarrow \mathrm{Y}$ & 0,000 & 0,117 & Linear \\
\hline
\end{tabular}

Setelah mengetahui bahwa hubungan antar variabel adalah linear, maka dapat dilanjutkan untuk analisis regresi linear berganda.

Tabel 6. Hasil Uji Korelasi

\begin{tabular}{lcc}
\hline Variabel & $\boldsymbol{r}$ & Tingkat hubungan \\
\hline $\mathrm{X}_{1} \rightarrow \mathrm{Y}$ & 0,440 & Sedang \\
$\mathrm{X}_{2} \rightarrow \mathrm{Y}$ & 0,554 & Sedang \\
$\mathrm{X}_{1} \rightarrow \mathrm{X}_{2}$ & 0,516 & Sedang \\
\hline
\end{tabular}

Dengan nilai $r$ tersebut, diperoleh kategori tingkat hubungan sedang. Artinya korelasi antar variabel penelitian berhubungan signifikan namun masih dalam kategori sedang. Dari hasil uji korelasi tersebut juga dapat diketahui nilai sumbangan efektif dari masing masing variabel. Kecerdasan interpersonal berpengaruh terhadap keterampilan berbicara dengan sumbangan efektif sebesar 44\%. Sementara itu, kepercayaan diri berpengaruh terhadap keterampilan berbicara dengan sumbangan efektif sebesar $55,4 \%$.

Setelah dilakukan uji asumsi klasik, dilakukan analisis regresi berganda dan didapatkan hasil uji $t$ pada Tabel 7 dan hasil uji $F$ pada Tabel 8 .

Tabel 7. Hasil Uji $t$

\begin{tabular}{ccccc}
\hline Variabel & $\boldsymbol{t}_{\text {hitung }}$ & $\boldsymbol{t}_{\text {tabel }}$ & sig & Keterangan \\
\hline $\mathrm{X}_{1}$ & 2,240 & 1,986 & 0,027 & $\begin{array}{c}\text { Signifikan } \\
\text { Positif }\end{array}$ \\
\hline $\mathrm{X}_{2}$ & 4,375 & 1,983 & 0,000 & $\begin{array}{c}\text { Signifikan } \\
\text { Positif }\end{array}$ \\
\hline
\end{tabular}

Tabel 8. Hasil Uji $F$

\begin{tabular}{ccccc}
\hline Model & $\boldsymbol{F}_{\text {hitung }}$ & $\boldsymbol{F}_{\text {tabel }}$ & Sig & Keterangan \\
\hline Regresi & 26,166 & 3,085 & 0,000 & $\begin{array}{c}\text { Signifikan } \\
\text { Positif }\end{array}$ \\
\hline
\end{tabular}


Hasil uji $t$ yang disajikan pada Tabel 7 didapatkan bahwa secara parsial, kecerdasan interpersonal berpengaruh signifikan dan ke arah positif terhadap keterampilan berbicara. Dan secara parsial kepercayaan diri berpengaruh signifikan ke arah positif terhadap keterampilan berbicara. Setelah didapatkan hasil uji parsial, dilakukan uji hipotesis simultan yang didapatkan pada Tabel 8. Dari hasil uji $F$ dapat disimpulkan bahwa hipotesis ketiga diterima. Artinya, secara simultan variabel kecerdasan interpersonal dan kepercayaan diri berpengaruh terhadap keterampilan berbicara.

Dari hasil analisis yang sudah dilakukan, bahwa kecerdasan interpersonal berkorelasi positif dan signifikan terhadap keterampilan berbicara. Hal ini mengindikasikan bahwa semakin tinggi kecerdasan interpersonal seseorang maka semakin tinggi pula keterampilan berbicara orang tersebut. Analisis ini sejalan dengan hasil penelitian yang menyatakan bahwa kecerdasan interpersonal berpengaruh positif dan signifikan terhadap keterampilan berbicara ([6], [7], [8], [15]). Bila kecerdasan interpersonal ini ada pada peserta didik, maka peserta didik tak akan kesulitan dalam menuangkan ide-idenya dalam bentuk bercerita di depan umum.

Kecerdasan interpersonal atau yang lebih dikenal dengan kecerdasan sosial merupakan merupakan kapabilitas seseorang dalam memahami serta menginterpretasikan motif dan suasana hati orang lain [16]. Selain itu, mampu memotivasi dan memberikan respon selektif dalam berkomunikasi, sehingga mudah bersosialisasi dengan lingkungan sekitarnya [17]. Dengan begitu, seseorang yang memiliki kecerdasan interpersonal tinggi mampu untuk berkomunikasi dengan baik dan menciptakan keakraban dalam interaksi sosialnya [18].
Namun, dari hasil penelitian ini ditemukan bahwa sebagian besar peserta didik kelas $\mathrm{V}$ memiliki kecerdasan interpersonal yang tergolong cukup rendah. Menurut beberapa ahli, seseorang yang memiliki kecerdasan interpersonal yang tinggi, akan memiliki tingkat kepekaan yang tinggi terhadap lingkungannya ([17] - [21]). Hal tersebut dinamakan sensitifitas sosial (social sensitivity). Social sensitivity adalah kemampuan seseorang dalam memahami perubahan respon seseorang berupa ekspresi, gestur tubuh, ataupun nada bicara. Dimensi ini terdiri dari dua indikator yaitu sikap empati dan sikap prososial [18]. Salah satu faktor yang dapat menyebabkan peserta didik kelas V memiliki sikap empati dan pro-sosial yang rendah adalah kecanggihan teknologi.

Peserta didik kelas $\mathrm{V}$ yang menjadi responden termasuk dalam generasi $\mathrm{Z}$, memiliki kemampuan dan ketertarikan lebih dalam penguasaan teknologi. Saat ini generasi muda lebih tertarik untuk bermain game online dan menggunakan media sosial lewat smartphone yang mereka miliki. Hal tersebut dibuktikan dengan penelitian tentang korelasi antara intesitas bermain game online dengan sikap antisosial peserta didik yang berumur antara 12-14 tahun [22]. Dari analisis penelitian tersebut didapatkan bahwa kedua variabel tersebut berkorelasi positif dan signifikan. Sebagai tindakan preventif dari hal tersebut, peneliti juga memberikan saran yaitu memberikan mediasi dari orang tua kepada anaknya untuk membatasi dalam penggunaan smartphone.

Kecerdasan interpersonal merupakan salah satu kemampuan yang dibutuhkan dalam menciptakan interaksi sosial yang terjadi di lingkungannya. Akibat rendahnya kecerdasan interpersonal peserta didik berdampak pada sulitnya peserta didik untuk bercerita terhadap ide-ide atau gagasan yang dimilikinya. Maka dari itu, 
diperlukan langkah untuk meningkatkan kecerdasan interpersonal peserta didik. Salah satu cara untuk meningkatkan kecerdasan interpersonal adalah dengan meningkatkan perhatian orang tua terhadap peserta didik. Hal ini berdasarkan penelitian [23] dan [24] tentang korelasi antar kedua variabel tersebut. Hasil penelitian tersebut menyatakan bahwa terdapat korelasi positif dan signifikan antara perhatian orang tua terhadap kecerdasan interpersonal peserta didik.

Sementara itu, dari hasil analisis yang sudah dilakukan, didapatkan bahwa kepercayaan diri berkorelasi positif dan signifikan terhadap keterampilan berbicara. Hal ini mengindikasikan bahwa semakin tinggi kepercayaan diri seseorang maka semakin tinggi pula keterampilan berbicara orang tersebut. Analisis ini sejalan dengan hasil penelitian yang menyatakan bahwa kepercayaan diri berpengaruh positif dan signifikan terhadap keterampilan berbicara ([9], [10], [11], [12]). Bila peserta didik memiliki kepercayaan diri yang tinggi maka peserta didik tak akan kesulitan dalam menuangkan ide-idenya dalam bentuk bercerita di depan umum.

Percaya diri merupakan sebuah hasrat seseorang yang dapat memotivasi dirinya untuk mengambil sebuah tindakan karena individu tersebut yakin bahwa hasil yang didapatkan akan sesuai dengan ekspektasinya [25]. Terdapat perbedaan pendapat antar peneliti mengenai faktorfaktor yang mempengaruhi kepercayaan diri seseorang. Namun terdapat garis besar persamaan bahwa kepercayaan diri seseorang dipengaruhi oleh dua faktor yaitu faktor yang berasal dari dalam diri (internal) dan yang berasal dari lingkungan (eksternal). Kedua faktor tersebut secara simultan berpengaruh terhadap kepercayaan diri seseorang. Individu yang memiliki kepercayaan diri yang tinggi akan mampu untuk memulai interaksi (komunikasi) sosial. Dengan adanya kepercayaan diri yang tinggi pada diri peserta didik, maka peserta didik tersebut akan mampu untuk bercerita di depan kelas dengan baik.

Kepercayaan diri peserta didik kelas V setidak-tidaknya akan dipengaruhi oleh karakteristik psikososial dan emosional mengingat mereka baru memasuki fase remaja. Dilihat dari segi psikososial, peserta didik kelas tinggi (kelas IV, V dan VI) memiliki kepercayaan diri yang lebih tinggi dibandingkan peserta didik kelas rendah. Hal tersebut karena peserta didik kelas tinggi secara umum memiliki keinginan untuk terlihat lebih dewasa dibandingkan peserta didik kelas rendah. Mereka ingin dianggap sebagai seseorang yang sudah dewasa. Akibatnya terjadi peningkatan kepercayaan diri. Selain itu, mereka akan berpikir bahwa tanggung jawab sebagai senior akan lebih berat. Dan mereka akan berpikir bahwa tangung jawab itu akan dibebankan pada dirinya dan juga teman-teman sebayanya. Maka dari itu, kesetiakawanan mereka sangat tinggi. Mereka akan berupaya penuh untuk bekerja dalam kelompok [26].

Dari segi emosional, mereka cenderung lebih menyukai sesuatu yang dilakukan oleh kelompok ketimbang individu. Mereka lebih berminat untuk mencapai tujuan bersama. Ketika konflik terjadi mereka dengan mudah mencari solusi dan saling memaafkan satu dengan lainnya. Mereka juga lebih bersemangat dalam bersaing satu dengan lainnya, sehingga tercipta sikap kompetitif namun tetap sportif. Namun di sisi lain, mereka lebih mudah untuk putus asa maka dari itu peran guru dan orang tua akan sangat berpengaruh [27].

Berdasarkan uraian singkat mengenai kepercayaan diri peserta didik kelas $\mathrm{V}$ ditinjau dari karakteristik psikososial dan 
emosional, didapatkan bahwa secara umum peserta didik kelas $\mathrm{V}$ akan memiliki kepercayaan diri yang tinggi. Hal tersebut juga dibuktikan dari hasil penelitian ini yang menunjukkan bahwa sebagian besar responden memiliki kepercayaan diri yang tinggi. Penelitian menunjukkan bahwa kepercayaan diri peserta didik kelas $\mathrm{V}$ di Kabupaten Buleleng masuk dalam kategori 'BAIK' [28]. Lebih lanjut, dijelaskan bahwa terdapat beberapa faktor yang mempengaruhi tingginya kepercayaan diri peserta didik kelas V yaitu (1) keterlibatan peserta didik dalam acara-acara sekolah (baik akademis dan non-akademis); (2) metode pembelajaran; (3) perhatian guru; serta (4) perhatian orang tua.

Kepercayaan diri merupakan salah satu kemampuan yang dibutuhkan dalam menciptakan interaksi sosial yang terjadi di lingkungannya. Akibat rendahnya kepercayaan diri peserta didik berdampak pada sulitnya peserta didik untuk bercerita terhadap ide-ide atau gagasan yang dimilikinya. Maka dari itu, diperlukan langkah untuk meningkatkan kepercayaan diri peserta didik sebagai upaya meningkatkan keterampilan berbicara peserta didik.

Banyak sekali metode dalam meningkatkan kepercayaan diri peserta didik salah satunya memberikan motivasi melalui sarana audiovisual. Sebuah studi literatur tentang hal ini, menyimpulkan bahwa pemberian motivasi kepada peserta didik melalui audiovisual dapat meningkatkan kepercayaan diri peserta didik [29]. Hal tersebut dilandasi dari fakta bahwa saat ini peserta didik kelas $\mathrm{V}$ merupakan manusia yang digolongkan dalam generasi $\mathrm{Z}$ dimana mereka memiliki kecenderungan untuk mudah memahami dan ketertarikan lebih terhadap teknologi. Maka dari itu, salah satu cara yang paling tepat untuk meningkatkan kepercayaan diri peserta didik adalah memberikan motivasi melalui sarana audiovisual.

Sejalan dengan [28], bahwa metode pembelajaran dapat meningkatkan kepercayaan diri peserta didik, Budianti dan Permata (2017) pernah meneliti tentang hal tersebut yaitu dengan mengaplikasikan metode bermain peran (role playing). Subjek penelitian adalah peserta didik kelas V sebanyak 43 orang. Dari hasil penelitian yang dilakukan Yudi, dengan menggunakan metode bermain peran berdampak pada peningkatan kepercayaan diri dari siklus I ke siklus II, dan dari siklus II ke siklus III berturut turut adalah $16,27 \%$ dan $4,66 \%$. Selain itu, masih menggunakan metode yang sama, juga terdapat peningkatan keterampilan berbicara dari siklus I ke siklus II, sebesar 13,95\% dan dari siklus II ke siklus III sebesar $6,98 \%$. Metode bermain peran terbukti efektif dalam meningkatkan kepercayaan diri dan keterampilan berbicara peserta didik kelas V.

Dari hasil penelitian ini, secara simultan, kecerdasan interpersonal dan kepercayaan diri memiliki korelasi positif dan signifikan terhadap keterampilan berbicara. Hal ini mengindikasikan bahwa semakin tinggi kecerdasan interpersonal dan kepercayaan diri seseorang maka akan semakin tinggi pula keterampilan berbicara peserta didik. Dari hasil statistik penelitian ini, sebagian besar responden memiliki nilai keterampilan berbicara dalam taraf ratarata. Namun, dalam proses pengambilan data, peneliti mendapatkan bahwa sebagian besar responden memiliki keberanian yang rendah. Peneliti mendapati bahwa sebagian besar responden masih enggan dan malu ketika dipanggil untuk tes praktik keterampilan berbicara.

Rendahnya keberanian peserta didik kelas $\mathrm{V}$ dalam berbicara di depan kelas sesuai dengan pendapat yang dikemukakan oleh 
Referensi [30]. Keterampilan berbicara di depan kelas sangat dipengaruhi oleh keberanian. Karena itu, diperlukan metodemetode untuk meningkatkan keberanian peserta didik dalam aspek keterampilan berbicara. Salah satu metodenya adalah dengan pembelajaran berbasis projek atau project-based learning (PBL). Selanjutnya, terdapat penelitian tentang pengaruh penerapan PBL terhadap keterampilan berbicara peserta didik kelas V [31]. Subjek yang digunakan adalah peserta didik kelas V dari sekolah SD Negeri Ajung 03 sebanyak 30 orang. Dari hasil penelitian yang dilakukan Sari, dengan menggunakan metode PBL berdampak pada peningkatan keterampilan berbicara peserta didik. Metode PBL terbukti mampu untuk meningkatkan keterampilan berbicara peserta didik.

\section{SIMPULAN DAN SARAN}

Berdasarkan dari hasil analisis didapatkan simpulan bahwa: (1) kecerdasan interpersonal berpengaruh signifikan ke arah positif terhadap keterampilan berbicara; (2) kepercayaan diri berpengaruh signifikan ke arah positif terhadap keterampilan berbicara; (3) secara simultan, kecerdasan interpersonal dan kepercayaan diri berpengaruh signifikan ke arah positif terhadap keterampilan berbicara peserta didik kelas $\mathrm{V}$.

Berdasarkan penelitian yang dilakukan, saran yang perlu disampaikan sebagai upaya dalam meningkatkan keterampilan berbicara peserta didik adalah: (1) meningkatkan perhatian orang tua dan guru terhadap peserta didik; (2) melibatkan peserta didik dalam kegiatan sekolah (baik akademis maupun non-akademis); (3) mengaplikasikan metode PBL pada pembelajaran; (4) memberikan motivasi melalui sarana audiovisual.

\section{DAFTAR PUSTAKA}

[1] M. Arsjad, Pembinaan Kemampuan
Berbicara Bahasa Indonesia. Jakarta: Erlangga, 1993.

[2] Supriyadi, "Upaya Meningkatkan Keterampilan Berbicara Siswa Kelas Rendah Sekolah Dasar," Ling. J. Bhs. dan Sastra, vol. 2, no. 6, pp. 178-195, 2005.

[3] P. Hyman, "Redesigning the Traditional Assembly," 2016. [Online]. Available: https://www.edutopia.org/blog/redesi gning-the-traditional-assembly-peterhyman.

[4] G. P. Leksono, "Kemampuan Berbicara Siswa Kelas Tinggi di SD Negeri 1 Kedunglegok, Kecamatan Kemangkon, Kabupaten Purbalingga," Universitas Negeri Yogyakarta, 2013.

[5] A. Hidayati,"Peningkatan

Keterampilan Berbicara melalui Pendekatan Komunikatif Kelas V SD Padurenan II di Bekasi Tahun Pelajaran 2016/2017," J. Ilm. Pendidik. Dasar, vol. V, no. 2, 2018.

[6] R. Pishghadam, "A Quantitative Analysis of the Relationship between Emotional Intelligence and Foreign Language Learning a Quantitative Analysis of the Relationship between Emotional Intelligence and Foreign Language Learning," no. January, 2016.

[7] D. A. Febrianti, "Pengaruh Kemampuan Verbal dan Keterampilan Menceritakan Pengalaman Pribadi Siswa Kelas X SMA Negeri 3 Rembang," 2017.

[8] U. Himmaturrofiah, "Correlation Between Students' Interpersonal Intelligence and Students' English Speaking Achievement of Seventh Grade at SMPN 01 Mlarak in Academic Year 2018/2019," State Institute of Islamic Studies, 2019.

[9] A. Fakhiroh dan S. Hidayatullah, "Pengaruh Percaya Diri terhadap Ketrampilan Berbicara," $J . \quad E l$ 
Ibtikar, vol. 7, no. 1, pp. 34-46, 2018.

[10] A. Syafitri, A. Yundayani, dan W. K. Kusumajati, "Hubungan antara Kepercayaan Diri Siswa terhadap Kemampuan Berbicara Bahasa Inggris," Pros. Semin. Nas. Pendidik. STKIP Kusuma Negara, pp. 1-8, 2019.

[11] B. Bukhori, "Kecemasan Berbicara di Depan Umum Ditinjau dari Kepercayaan Diri dan Keaktifan dalam Organisasi Kemahasiswaan," J. Komun. Islam, vol. 06, no. 01, 2016.

[12] S. Wahyuni, "Hubungan antara Kepercayaan Diri dengan Kecemasan Berbicara di Depan Umum pada Mahasiswa Psikologi," J. Psikoborneo, vol. 1, no. 4, pp. 220-227, 2013.

[13] I. Ghozali, Aplikasi Analisis Multivariate dengan Program SPSS. Semarang: Badan Penerbit Universitas Diponegoro, 2011.

[14] I. W. Koyan, Statistik Pendidikan Teknik Analisis Data Kuantitatif. Singaraja: Universitas Pendidikan Ganesha Press, 2012.

[15] J. Irianto, "Hubungan Kecerdasan Interpersonal dan Perhatian Orang Tua dengan Keterampilan Berbicara Bahasa Inggris Siswa (Survei pada SMA Negeri 21 Jakarta)," Universitas Negeri Jakarta, 2010.

[16] J. R. Prasetyo dan Y. Andriani, Multiply your Multiple Intelligences: Melatih 8 Kecerdasan Majemuk pada Anak dan Dewasa. Yogyakarta, 2009.

[17] H. Gardner, Multiple Intelligences. Batam: Interaksara, 2003.

[18] T. Safaria, Interpersonal Intelligence. Yogyakarta: ANDI, 2005.

[19] N. Hanafiah dan C. Suhana, Konsep Strategi Pembelajaran. Bandung: Refika, 2009.
[20] S. J. Stein and H. Book, Ledakan EQ: 15 Prinsip Dasar Kecerdasan Emosional Meraih Sukses. Bandung: Kaifa, 2002.

[21] D. Goleman, Kecerdasan Emosional (Alih Bahasa: T. Hermaya, Judul Asli: Emotional Intelligence). Jakarta: PT Gramedia Pustaka Utama, 2005.

[22] A. Rahmawati, "Pengaruh Intensitas Bermain Game Online dan Mediasi Restriktif Orang Tua terhadap Perilaku Antisosial Remaja," Universitas Diponegoro, 2015.

[23] A. Faruk, "Hubungan Perhatian Orang Tua dengan Kecerdasan Interpersonal Siswa Kelas V SD Negeri di Kelurahan Mangkang Kulon, Kecamatan Tugu, Kota Semarang," Universitas Negeri Semarang, 2016.

[24] P. A. Saputro, "Hubungan Perhatian Orang Tua terhadap Prestasi Belajar IPS dan Kecerdasan Interpersonal Siswa SD Kelas III," J. PGSD, vol. 8, no. 13, 2015.

[25] T. Hakim, Mengatasi Rasa Tidak Percaya Diri. Jakarta: Purwa Suara, 2005.

[26] Suyati, Pelajaran Senam. Jakarta: Alpha Beta, 1992.

[27] E. B. Hurlock, Psikologi Perkembangan: Suatu Pendekatan Sepanjang Rentang Kehidupan (alih bahasa: Istiwidayanti, Soedjarwo), 5th ed. Jakarta: Erlangga, 1996.

[28] I. G. A. F. Widyanti, I. K. Sudarma, P. N. Riastini, J. Pendidikan, dan G. Sekolah, "Kecenderungan Kualitas Rasa Percaya Diri Siswa Kelas V SD Negeri 2 Sukasada Kabupaten Buleleng," 2017.

[29] R. Aristiani, "Meningkatkan Percaya Diri Siswa melalui Layanan Informasi Berbantuan Audiovisual," J. Konseling GUSJIGANG, vol. 2, no. 2, pp. 182-189, 2016.

[30] M. G. Arsjad dan U. S. Mukti, 
Pembinaan Kemampuan Berbicara Bahasa Indonesia. Jakarta: Erlangga, 1998.

[31] L. I. Sari, H. Satrijono, dan Sihono, "Penerapan Model Pembelajaran Berbasis Proyek (Project Based Learning) untuk Meningkatkan Hasil
Belajar Keterampilan Berbicara Siswa Kelas VA SDN Ajung 03 (The Application of Method Project Based Learning for Improving Learning Outcomes on Speaking Skill o," J. Edukasi UNEJ, vol. II, no. 1, pp. 1114, 2015. 